\title{
SEXIST STEREOTYPES AND BIASES ASSOCIATED WITH THE FEMALE NURSING MODEL IN ADVERTISING COMMUNICATION
}

\author{
Manuel-Ángel Calvo-Calvo
}

\footnotetext{
${ }^{1}$ Ph.D. at Universidad de Sevilla. Associate Professor Department of Nursing and do School of Nursing, Physiotherapy and Podiatry, Universidad de Sevilla. Sevilla, España. E-mail: macalvo@us.es
}

\begin{abstract}
In the media, gender stereotypes and biases appear that transmit a sexist representation of women. The aim of this study was to know the sexist stereotypes and biases that are projected on female nurses in advertising campaigns and to identify the characteristics of the female nurse model shown in advertising. A qualitative study was performed on four campaigns featuring female nurses in white dresses and caps, using descriptive and inferential content analysis. Conclusions show that female nurses appearing in advertising transmit both sexist stereotypes (female profession, gentleness, lack of control, strong affectivity, frivolousness, passivity, submissiveness, commitment to basic care, merely sexual and aesthetic value) and sexist biases (androcentrism and double standards). In particular, advertising propagates the model of the seductive nurse, depicted as a young, attractive, sensual and defiant woman that is used merely as a decorative presence.
\end{abstract}

DESCRIPTORS: Advertising as topic. Female. Nurse's role. Stereotyping. Prejudice.

\section{ESTEREOTIPOS Y SESGOS SEXISTAS ASOCIADOS AL MODELO DE MUJER ENFERMERA EN LA COMUNICACIÓN PUBLICITARIA}

RESUMEN: En los medios de comunicación aparecen estereotipos y sesgos de género que transmiten una representación sexista de la mujer. El objetivo del estudio fue conocer los estereotipos y sesgos sexistas que se proyectan sobre las mujeres enfermeras en acciones publicitarias, e identificar las características del modelo de mujer enfermera que transmite la publicidad. Se realizó un estudio cualitativo mediante análisis de contenido descriptivo e inferencial, de cuatro acciones publicitarias donde aparecían mujeres enfermeras con vestido y cofia blanca. Se concluye que cuando la mujer enfermera aparece en la publicidad se transmiten estereotipos sexistas sobre ella - profesión femenina, ternura, falta de control, afectividad marcada, frivolidad, pasividad, sumisión, dedicación a cuidados elementales, simple valor estético y sexual-, y sesgos sexistas -el androcentrismo y la doble moral-. En la publicidad se transmite, sobre todo, el modelo de enfermera seductora, caracterizado como mujer joven, atractiva, sensual y desafiante, con presencia simplemente decorativa. DESCRIPTORES: Publicidad como asunto. Femenino. Rol de la enfermera. Estereotipo. Prejuicio.

\section{ESTEREÓTIPOS E SINAIS SEXISTAS ASSOCIADOS AO MODELO DA MULHER ENFERMEIRA NA COMUNICAÇÃO PUBLICITÁRIA}

RESUMO: Os meios de comunicação apresentam estereótipos e sinais "machistas" que transmitem uma representação sexual da mulher. O objetivo deste estudo foi conhecer os estereótipos e sinais sexistas projetados sobre as mulheres enfermeiras em ações publicitárias e identificar as características da mulher enfermeira descrita pela publicidade. Realizou-se um estudo qualitativo, mediante análise de conteúdo, de caráter descritivo e inferencial, a partir da análise de quatro peças publicitárias em que apareciam mulheres enfermeiras com vestido e quepe branco. Conclui-se que quando a mulher enfermeira aparece na publicidade são transmitidos estereótipos sexuais sobre ela - profissão feminina, ternura, falta de controle, afetividade marcada, frivolidade, passividade, submissão, dedicação a cuidados básicos, simples valor estético e sexual; e sinais - o androcentrismo e a norma dupla. Na publicidade transmite-se, sobretudo, a imagem da enfermeira sedutora caracterizada pela imagem de uma mulher jovem, atrativa, sensual e desafiante, com presença simplesmente decorativa.

DESCRITORES: Publicidade como assunto. Feminino. Papel do profissional de enfermagem. Estereotipagem. Preconceito. 


\section{INTRODUCTION}

The advertising phenomenon has fully entered into the lives of millions of people, with discourse in emotive and seducing contexts, so as to attract these receivers' attention to the products announced. But advertising can also project stereotypes and negative bias to different sociocultural aspects in almost the entire global population.

Stereotypes are non-scientific generalizations about what is considered characteristic of each gender and biases are the prejudices the stereotypes produce. ${ }^{1}$ Due to their consequences, the gender-related stereotypes and biases stand out, as they transmit a sexist representation of women, which produce adverse effects in society and in women.

Hence, in the social communication media, including advertising and movies, women are frequently reduced to the private sphere, ${ }^{1}$ simplistic, negative, mistaken or violent images are projected on them or prejudices are still transmitted about the presumed male superiority in terms of intellectual capacity, leadership, efficacy or aptitude. ${ }^{2}$ Although the female image advertising projects has positively been modified in favor of women in recent years, ${ }^{3}$ in advertising and other social communication media, people are still instructed to understand the relations between men and women in a certain manner, which maintain an asymmetric, discriminatory and stereotyped situation of women with respect to men. ${ }^{2}$

Among the sexist forms in which women are represented in advertising and other media like the movies or television, they frequently appear with the uniform nurses have traditionally worn, including a white skirt, cap and sometimes an apron. This way in which the media recurrently represent the nurses do not seem to be in accordance with the reality, nor convenient for the nurses' social image ${ }^{4}$ as, besides exceptions marked by tradition, the cap and apron currently tend to be eliminated from the work uniform of female nurses. Part of this group even rejects these clothes, considering that they are sexist and discriminatory with regard to the position of men in the same profession. In this respect, the media repercussion of nurses' protests at a clinic in Spain are reminded, because they were obliged to work wearing skirts, cap and apron and even had to turn to the courts to avoid the imposition of these work clothes. ${ }^{5}$

It is known that the effects of the stereotypes and bias the communication media transmit about the nurses are largely responsible for the distorted image of nurses in the public opinion. ${ }^{4}$ Therefore, different authors have unveiled the stereotypes and bias projected on the nurses in their professional practice, ${ }^{6-8}$ and through communication media like the movies and the written press. ${ }^{9-13}$ There are few studies about stereotypes, bias and the personal and professional characteristics projected in the social imaginary when, in such a powerful and influential communication medium as advertising, female nurses are represented wearing their traditional uniform with the skirt and white cap. Due to this lack of knowledge, the stereotypes and bias advertising projects on female nurses should be verified, as these exert an important influence on the construction of the nurses' image in the mind of the publics. In addition, it should be kept in mind that advertising is a powerful and influential mass communication medium, as an important agent of quasi universal socialization and a social instrument to learn conducts and create and consolidate models for imitation. ${ }^{1}$

Nevertheless, it is observed that, generally, the nurses take interest in and are hardly concerned with discussing and getting deeper into the action and effects the mass communication media, including advertising, exert on the nurses' image and social identity, perhaps due to the lack of awareness that the media are largely responsible for the construction of the image of how society perceives the nurses. ${ }^{4}$

Consequently, the general objective in this study was to get to know the sexist stereotypes and biases projected on the female nurses when they appear in advertising wearing a skirt and white cap, as well as to identify the characteristics of the female nurse model transmitted to the receivers through this advertising.

\section{METHOD}

A qualitative study was undertaken through descriptive and inferential content analysis. This analysis was applied to advertising images and texts at the contextual, morphological, compositional-syntactic and declarative-interpretative levels. This research was undertaken between October and November 2012.

\section{The main data sources}

To respond to the research objectives, advertising actions were sought that showed nurses in 
their traditional uniform, that is, at least the dress and white cap. This search was undertaken in audiovisual material databases like tvanuncios.com (http://www.tvanuncios.com), Publi.tv (http:// www.publitv.com) and YouTube (http://www. youtube.com). From the search results, three advertising actions were selected for analysis and, because of its relevance to achieve the research objective, it was considered suitable to analyze a fourth advertising action, precisely the photograph that illustrated a news item published in different communication media.

\section{Advertising action 1}

Television commercial for an anti-dandruff shampoo, in Spanish, available on the website http://www.youtube.com/ watch?v=pJ9myJudELs. Versions in English, Portuguese and other languages also exist. In the commercial, a young athlete is shown who is naked from the waist up, in the shower of a locker room. He is surprised because, when looking at the shampoo announced and opening a curtain, six young women appear in front of him dressed as nurses, wearing a very tight white dress with a large cleavage, cup in the same color, dark tights and red high-heeled shoes. The nurses dance and sing around a smiling and pleased protagonist, soap his head and hair, touch and rest on his body, accompanied by insinuating, sensual and provocative body postures, gestures and winks of these six women towards the young man.

The text the nurses sing in this commercial says that "hair like this has never been seen, smelling your shampoo drives us mad, clean and so fresh and natural, don't you just love moments like these, fresh, brilliant and virile, finally a man without dandruff".

\section{Advertising action 2}

Similar television commercial of the same shampoo, in English, available on the website http://www.youtube.com/ watch? $\mathrm{v}=\mathrm{dhnOwSuv} 4 \mathrm{p} 8$. The center of the image shows a young man with a serious and harsh expression, wearing a bathrobe and with his hair soaped. Behind him, four women dressed in the same traditional nursing clothes, as in the commercial described earlier, dance to the rhythm of a theme song also in English. These nurses also rub his head and hair, touch and rest on his body, accompanied by the same insinuating, sensual and provocative body postures, gestures and winks of these four women towards the young man.

\section{Advertising action 3}

Television commercial, in Spanish, which advertises for a chain of snack bars and fast food restaurants, available on the professional portal tvanuncios.com (http://www.tvanuncios.com/ spot-pans-and-company-enfermera). In the announcement, a robust and mature woman in a white dress, apron and cap and serious and intimidating gestures, holds a huge snack wrapped in a white cloth in each arm, as if it were newborns, making forced gestures and fawning all over them. This nurse reaches the waiting room of a maternal hospital where a young concerned man is sitting and waiting. The commercial says and displays "Freshly made snacks ... irresistible", after which the nurse cannot resist these snacks, freshly made as if it were newborns, and with great energy takes a big bit out of each snack. Then, the nurse leaves the room, demonstrating her satisfaction between jumps and smiles of complacency and enjoyment.

\section{Advertising action 4}

Photograph that illustrated the information published in different media about an institutional communication act. ${ }^{14}$ This act informed about a surgery and esthetic treatment company's going public, when part of its stock started being sold on the stock exchange. The photograph, taken in the trade room of the headquarters of the Madrid Stock Exchange (Spain), shows a man in a suit and tie at the center of the room, decorated with the company's name. The man is reading in front of a microphone, surrounded by 50 young women. They are wearing very short skirts, sleeveless jackets with a big cleavage and cap, all white, with a blue stethoscope hanging from the neck of each of these nurses. ${ }^{14}$

\section{Analysis process}

To analywe these four selected advertising actions, content analysis was used, with the double goal of describing the characteristics of the communicative process - what appears and what is said in the commercial message -, and formulating inferences about processes external to the content of the communication - who, why and with what effect the commercial message is presented. ${ }^{15}$ 
To undertake that content analysis in these two descriptive and inferential branches, an analysis instrument of sexist stereotypes and biases was used, previously elaborated by other authors, ${ }^{1}$ as that instrument has been validated and can be applied to any type of advertising, independently of the dissemination medium. Through the analysis instrument, indicators were identified that indicated that, in the advertising analyzed, female and male stereotypes appeared linked to personality traits and social, political, family and professional roles. Also, indicators were identified that, in this advertising, biases are projected such as androcentrism, double standards and sexual dichotomy. ${ }^{1} \mathrm{Be}-$ sides the study of these attributes, it was considered convenient to add information about two additional indicators, as other authors propose: ${ }^{16}$ the relations between the nurses and the product announced, distinguishing between functional and decorative presence, and the physical appearance of the female model present in the advertising, distinguishing between seducing and non seducing models.

Based on the study of these indicators, the sexist stereotypes and biases could be established as the analytic criteria that appear in the communicative actions under study, applying these criteria to two fundamental fields or analysis units: the linguistic code and the iconic code.

\section{RESULTS AND DISCUSSION}

The clothing, with a white skirt and cap, which the women wear in the advertising analyzed enables their identification as nurses. As this is a role or profession whose performance has traditionally been considered characteristic of women, in this advertising, the stereotype of nurses appears as a profession traditionally linked with the female gender, ${ }^{17}$ as a variant of the professional role stereotypes.

Except in advertising action 3, the female nurses are generally represented wearing clothes they generally do not wear in their professional practice, such as very short, tight dresses with deep cleavage that clearly mark the contours and silhouettes of the women's body, including red high-heeled shoes like in advertisements 1 and 2. This form of highlighting the women's body through their clothes is combined with the nurses' actions in these same advertisements, which are also improper of their professional practice, such as dancing and singing around a naked man, with forced and hardly natural insinuating, sensual and provocative body postures, gestures and winks.
According to the analysis criteria, ${ }^{1}$ this form of showing the nurses in the commercials projects and reinforces messages, including that these are provocative women, with clear affection, and they are even represented with a loss of control of their actions, by touching the man's body without objectives characteristic of nursing practice. The linguistic code in announcement 1 , that is, the music and lyrics of the song the nurses sing, reinforces these messages that project the iconic code of the commercial on them, as the nurses sign to highlight masculine characteristics of the young man in the announcement: "...smelling your shampoo drives us mad, clean and so fresh and natural, don't you just love moments like these, fresh, brilliant and virile, finally a man without dandruff...".

These indicators reveal that, in the advertising analyzed, other stereotypes are linked with the nurses' personality traits, such as tenderness, lack of control, clear emotions and frivolity. In addition, this daring clothing, improper of professional nurses and which highlights their body, also shows the female nurses as beautiful, young, provocative, seducing and as objects of consumption but, in line with another study, ${ }^{18}$ in the advertising analyzed, the social stereotype of women as simple esthetic and sexual value is also projected on the nurses. ${ }^{1}$

The nurses are presented as such to add an additional sexual and erotic loading to this advertising, which is not related to the nurses' professional knowhow and is aimed at influencing the sexual instincts in the receivers of the publicity. Consequently, the nurses are used here as sexual advertisements to announce products mostly directed at men, which is why the figure of the female nurse is reduced to a mere sexual object, in order to attract and call the men's attention to the products published. ${ }^{18}$

This form of presenting the nurses in the advertising actions analyzed as mere sexual objects is able to sexually objectify the women. As a result, these female nurses appear as simple elements of the advertising context to awake, attract and maintain the attention of the public, mostly male.

Similarly, according to the relation of the female nurses and the announced products, ${ }^{16}$ their presence in the advertising is also decorative as, functionally, they are not related to the products announced in the commercials analyzed. In fact, as the nurses are not professionally related to the products they announce - shampoo, snacks and fast food and the sale of company stock, these 
nurses lack professional or social protagonism in these advertising actions. Consequently, this is also in accordance with Chacón, ${ }^{18}$ in that women in this advertising context only have a decorative value, representative of esthetic canons and as sexual objects.

In addition, as a result of the improper and daring clothing that highlights the nurses' body and the stereotypes projected on them in these announcements, according to their physical appearance ${ }_{1}^{16}$ the female nurses who appear in this publicity correspond to the model of the seducing woman, in which man is conceived as a victim of her seducing and manipulative action. Therefore, in the advertising analyzed, the nurses are represented from a sexual and playful perspective, which coincides with findings ${ }^{6}$ that signal that, in line with this model of seducing woman, the nurse is seen as a woman of doubtful morals, uninhibited and sexually very tempting. This advertising perspective of the nurse image also coincides with this professional stereotype called the naughty nurse. ${ }^{8}$

In the announcements 1 and 2, besides dancing, singing and touching the young man's body, the nurses scrub his soaped hair, which indicates the presence of the stereotype linked to social roles of women dedicated to elementary activities and care in the advertising analyzed. This stereotype remains far from the performance of technical, research, management and command activities, which are almost always associated to men. ${ }^{1}$

This idea is reinforced by the iconic code of advertising actions 1,2 and 4, in which man is always at the forefront or center of the scene, surrounded by the female nurses in the peripheral areas of the image. This distribution of the characters transmits the idea of man's central or dominant position in relation to women, and that the latter occupy an inferior and position subordinated to men. That is, in this advertising, the ideas of the protagonism of men over women and the male order of priority in the social hierarchy appear as sexist indicators, which show the presence of the bias of androcentrism in these advertising actions. This hierarchical structure, with strong sexual connotations, reproduces the male dominance and consolidates sexist stereotypes based on the patriarchal representation of the unequal position of women as passive agents and men as active actors. ${ }^{19}$

In addition, men are assigned roles or functions as, in announcements 1 and 2, they are represented in the role of athletes and, in announce- ment 4, wearing a suit and tie and giving an oral speech, which is why man appears represented as a manager, which directing and command activities and functions. On the opposite, the women are not assigned specific roles because the 50 nurses surrounding this male manager appear sitting, static and passive in the peripheral areas of the image, without any protagonist role and solely as decorative figures of the act. Consequently, these indicators manifest that, in the announcement analyzed, stereotypes appear linked to personality traits of the female nurses, such as passiveness, submission, sweetness and subordination in their professional knowhow.

Also, these indicators present in the advertising actions transmit that activity is combined with men and passivity with women, and associate the delivery of elementary healthcare with women, and technical, research, management and command activities with men, transmitting the bias of double standards in the advertising analyzed. Nevertheless, the nurse in announcement 3, capable of eating the snacks-babies, is represented making gestures of tenderness, but also displaying a lack of self-control and aggressiveness, as she cannot resist the temptation of eating these snacks-babies. This indicates that, in this announcement, other stereotypes are projected on nurses, linked with personality traits like tenderness and aggressiveness, the latter being a sexist stereotype that usually applies to women. Consequently, in this advertising context, these results are also in accordance with authors who identify the professional stereotype of the battleaxe nurse, ${ }^{8}$ referring to that female nurse who performs her profession aggressively and can even create a more fearsome environment of hostility than a man could. ${ }^{6}$

With regard to these sexist stereotypes and biases detected in this study, by using the model of the female nurse in advertising, it can be affirmed that the advertising discourse continues excluding women from roles of power and continues restricting them to professional roles that are considered characteristic of women and in sensual spheres, according to men's understanding and perception. Therefore, this advertising discourse about the female nurse is devised departing from the male hegemony and continues being constructed in order to be activated from within that hegemony.

Also, in this advertising discourse of man's dominance over woman, the stereotypes or attributes considered characteristic of the female nature are projected as indispensable for healthcare 
delivery. Thus, this advertising contributes for the nursing profession to continue being considered an extension of the role women play at home as wife, mother and housewife, in the performance of functions linked to care for other people,$^{20}$ in accordance with Espín et al, ${ }_{1}^{1}$ when they refer to the fact that advertising still displays an idea of female essence compulsorily combined with maternity and with housework and family care, as obligations inherent to women.

In addition, these sexist stereotypes and biases projected on the female nurse model are constantly updated and interpreted in the light of the stock of codes the receivers have learned. As a result of this recycling, the reporting and discursive plot of the female in this advertising is unreal, superficial, constructed for and exclusively centered on men, given that it intends to persuade and seduce them, not with arguments but with discourse and images with an explicit sensual and erotic loading.

In this subliminal association between the nurses' perceived image and combination between sensuality and erotism produced in the minds of the receivers, the beliefs learned and socially transmitted values about the nurses again play an important role as, traditionally, different professional and social stereotypes have applied to the nurse image, like that of doctor's assistant, bold and feisty nurse or the nurse-guardian angel..$^{8}$

Other authors call the latter professional stereotype of nurse-guardian angel the "mother/ nun/servant" nurse, willing to deliver the amount of care needed to attend to all basic human needs. ${ }^{7}$ When this stereotype is reinterpreted in the receivers' imagination and background knowledge and taken completely literally in the affective and sexual spheres, in the collective imaginary, the idea still continues that the nurse also takes care of and satisfies needs in those areas.

This idea, which goes back a long time, has continued and even been strengthened further in the collective imaginary in the past century, when the nursing images were used and abused in the pornographic industry. In that sense, the cinema $\mathrm{X}$ has also presented nurses, to say the least, as frivolous, sexually attractive and provocative, with a prevailing scarce intellectual level, zero decisionmaking ability, subordination and dependence on other professionals. ${ }^{4}$

Hence, these results agree that, with regard to the women displayed in the advertising analyzed, in this case nurses, negative practices ${ }^{21}$ are highlighted, such as the invisibility and even ridiculing of women, the coexistence of stereotypes that relate the women with esthetic patterns, the reinforcing of traditional roles that minimize the female universe to a private-domestic sphere, the male worldview as the model women need to follow and the representation of women as personobject in the media.

One consequence of all this is that, through the advertising communication, it is transmitted to society that the sexist stereotypes and biases identified in this research are personal or professional characteristics of the female nurses, and that they communicate certain virtues that are considered applicable to each of the female nurses merely due to the fact of belonging to this group. In this case, the messages in the advertising actions analyzed project and reinforce sexist stereotypes and biases with negative connotations for nurses' image and personal, professional and social consideration, contributing to society's continuing unreal image of the nursing identity.

To counter and avoid these negative effects, it is still desirable to encourage critical awareness in the public of the communication media and to tend towards education for equalitarian citizenship, in which sexism is addressed more deeply in the academic curriculum and further specialization of journalists and advertisers. ${ }^{1}$ It should also be kept in mind that, although these communication professionals, mediators between the current reality and the public, acknowledge that the nurses are key to the care process, these professionals require further information, visibility and voice of the nurses in relation to their professional role. ${ }^{22}$ That is, they claim greater professional protagonism for the nurses in the communication media.

In fact, the nurses themselves do not counter these sexist and negative stereotypes and biases the social communication media transmit about the nurses through positive messages in the media that communicate their true identity. The tradition, which tends to be perpetuated, that the nurses, individually and as a group, are not particularly sensitive to and concerned with effective and appropriate communication of their true identity to society, is also responsible for the survival of these stereotypes and for the lack of coincidence between the nurses' identity and the image society has of nurses. ${ }^{4}$ Repairing or countering the above undoubtedly demands greater concern and learning from the nurses with a view to effectively relating with the social communication media, both 
individual and collectively, not living with their back turned towards the media and understanding the mechanisms to make sure that the nurses themselves manage their own communication acts and transmit their true identity.

The nurses should not postpone the practice of these communication strategies for a long time as, when they do not communicate their identity in accordance with their interests, external persons and the social communication media mostly transmit messages to the public and society that shape the nurses' professional identity. Under these circumstances, when the messages are issued and created beyond the nurses' control, there is a great probability of transmitting and maintaining an image of the nurses that does not correspond to reality. ${ }^{4}$ Therefore, as some authors claim, ${ }^{4,22}$ the nurses' own voice needs greater public presence, both individually and as a group, showing their true role and identity. Thus, the nurses themselves communicate their knowhow and contributions to society, controlling the communication process, countering the stereotypes and negative biases transmitted about them and contributing to transmit their true identity to the publics. ${ }^{4}$

Much remains to be investigated in the study of the nurses' stereotyped and sexist image, in the sexist media discourse and in how the nurses' true professional identity is publicly communicated. Therefore, it would be convenient to develop this same research applied to other social communication media, such as the radio, television or the written press, and even the Internet. In addition, it would also be convenient to investigate the nurses' awareness raising, attitude and predisposition to publicly communicate their actions and activities, and the available resources and communication skills needed for the nurses to effectively communicate their identity in public.

\section{CONCLUSIONS}

In advertisements that show female nurses wearing a skirt and white cap, sexist stereotypes are transmitted, such as the stereotype of the nurses' professional role as a profession traditionally linked to the female gender. This stereotype has appeared in two variants: on most occasions, the nurse is represented through the professional stereotype of seducing nurse and, in a minority, through the stereotype of the battleaxe nurse. Other stereotypes are linked with personality traits of the nurses, such as tenderness, lack of control, clear affection, frivolity, passivity, submissiveness, sweetness and subordination in their professional knowhow. Similarly, two stereotypes were detected that are linked to social roles: that of the woman dedicated to elementary activities and care, and of the woman considered a simple esthetic and sexual value. In these advertising actions that represent the women, two sexist biases are also transmitted: androcentrism and double standards.

The female nurse model that is mainly transmitted in advertising communication corresponds to the seducing nurse model who, in addition, has a merely decorative presence in advertising actions. This seducing nurse model is characterized because the nurse is mainly represented from a sexual-playful perspective, as a young, passive, attractive, sensual and challenging woman. To a lesser extent, the nurse is also represented in advertising as a tall and aggressive woman, showing the co-existence of two asymmetric models of female nurses in the advertising analyzed.

\section{REFERENCES}

1. Espín JV, Marín MA, Rodríguez M. Análisis del sexismo en la publicidad. Rev Invest Educ. 2004 Ene-Jun; 22(1):203-31.

2. Lomas C. ¿El otoño del patriarcado? El aprendizaje de la masculinidad y de la feminidad en la cultura de masas y la igualdad entre hombres y mujeres. Cuadernos Trabajo Social. 2005 Ene-Dic; 18:259-78.

3. Lopez-Zafra E, Garcia-Retamero R. Do gender stereotypes change? The dynamic of gender stereotypes in Spain. J Gender Studies [online]. 2012 Jun [acesso 2012 Nov 26] 21(2):169-83. Disponible en: http:/ / dx.doi.org/10.1080/09589236.2012.661580

4. Calvo-Calvo MA. Imagen social de las enfermeras y estrategias de comunicación pública para conseguir una imagen positiva. Index Enferm [online]. 2011 Jul-Sep; [acesso 2012 Nov 27] 20(3):184-8. Disponíble en: http:/ / www.index-f.com/index-enfermeria/ v20n3/0184.php

5. Diario de Cádiz [online]. Clínicas Pascual acepta cambiar el uniforme de su personal de Enfermería. 2011 [acesso 2012 Nov 27]. Disponíble en: http:/ / www.diariodecadiz.es/article/andalucia/1098853/ clinicas/pascual/acepta/cambiar/ uniforme/de/ su/personal/de/enfermeria.html

6. Burguete MD, Alcalá L. Estereotipos de género y enfermería. Educare 21 [online]. 2007; 38 [acesso 2012 Dic 6]. Disponible en: http://www.enfermeria21. com/educare/secciones/ensenyando/detalle_ index.ph p M \% 3 D \% 3 D \& M T M 1 \& MjU \% 3D\&MjE4MQ\%3D\%3D

7. Burguete MD, Martínez JR, Martín G. Actitudes de género y estereotipos en enfermería. Cult Cuidad. 2010 Jul-Dic; 28:39-48. 
8. Ferns T, Chojnacka I. Angels and swingers, matrons and sinners: nursing stereotypes. Br J Nurs. 2005; 14(19):1028-32.

9. Almansa P. Enfermería y cine posfranquista: una visión frívola. Enferm Global [online]. 2004 May [acesso 2012 Dic 12]; 3(1). Disponíble en: http:// revistas.um.es/eglobal/article/download/596/618

10. Andina E, Bonet P. La enfermería en "Hable con ella". Index Enferm [online]. 2004 Ene-Jun [acesso 2012 Nov 22]; 13(44-45). Disponble en: http:// dx.doi.org/10.4321/S1132-12962004000100015

11. Heierle C. La imagen de la enfermera a través de los medios de comunicación de masas: la prensa escrita. Index Enferm [online]. 2009 Abr-Jun [acesso 2012 Nov 28]; 18(2):95-8. Disponible en:http://www. index-f.com/index-enfermeria/v18n2/6945.php

12. Silex J, Cibanal L, García E. La enfermería en el cine: Imagen durante la Guerra Civil Española. Rev Rol Enferm. 1998 Dic; 244:25-8.

13. Silex J. Origen de la enfermería en el cine: el género histórico-documental y biográfico. Quaderns de Cine. 2009; 4:57-70.

14. Diario El País [online]. Corporación dermoestética sube un $18,90 \%$ en su debut en bolsa. 2005 [acesso 2012 Nov 20]. Disponible en: http:// economia.elpais.com/economia/2005/07/13/ actualidad/1121239973_850215.html

15. Gaitán JA, Piñuel JL. Técnicas de investigación en comunicación social. Elaboración y registro de datos.
Madrid (ES): Síntesis, 1998.

16. Royo M, Aldás J, Küster I, Vila N. Roles de género y sexismo en la publicidad de las revistas españolas: un análisis de las tres últimas décadas del siglo XX. Comun Socied. 2005 Ene-Jun; 28(1):113-52.

17. Santo-Tomás M. Mujeres, educación y sociedad. In: de la Rosa C, Dueñas MJ, del Val MI, Santo-Tomás M coord. Nuevos enfoques para la enseñanza de la Historia: Mujer y género ante el espacio europeo de educación superior. Colección Laya. Madrid (ES): Asociación Cultural Al-Mudayna; 2007

18. Chacón P. La mujer como objeto sexual en la publicidad. Comunicar. 2008 Oct; 16(31):403-9.

19. Oliveira VL. A construção do feminino e do masculino no processo de cuidar crianças em pré-escolas. Texto Contexto Enferm. 2006 Jul-Sep; 15(1):35-42.

20. Franco TC, Alencar I. A mulher e a enfermeira na nova ordem social do Estado Novo. Texto Contexto Enferm. 2008 Jul-Set; 17(3):587-93.

21. García-Muñoz N, Martínez L. El consumo femenino de la imagen de la mujer en la publicidad. El sexismo en las campañas publicitarias rechazadas por la audiencia. Trípodos. 2009; 24:149-60.

22. Kemmer LF, Silva MJP. Nurses' visibility according to the perceptions of the communication professionals. Rev Latino-Am Enferm [online]. 2007 [accesso 2012 Dic 10]; 15(2):191-8. Disponível em http://dx.doi. org/10.1590/S0104-11692007000200002 